\title{
Effect of temperature change on power generation of microbial fuel cell
}

\author{
L.H. Li, Y.M. Sun*, Z.H. Yuan, X.Y. Kong and Y. Li \\ Guangzhou Institute of Energy Conversion, Chinese Academy of Sciences, CAS Key Laboratory of Renewable Energy, No.2, Nengyuan \\ Rd, Wushan, Tianhe District, Guangzhou 510640, People's Republic of China
}

(Received 19 October 2012; accepted 11 July 2013)

\begin{abstract}
Microbial fuel cell (MFC), which can directly generate electricity from biodegradable materials, has been receiving increasing attention. Effects of temperature change on power density, electrode potential, columbic efficiency, chemical oxygen demand removal and internal resistance in two chambers MFCs were examined in this paper. The maximum power density of $7.89 \mathrm{~W} / \mathrm{m}^{3}$ was achieved at $37^{\circ} \mathrm{C}$, with $199 \%$ higher at $10^{\circ} \mathrm{C}\left(2.64 \mathrm{~W} / \mathrm{m}^{3}\right), 24 \%$ higher at $30^{\circ} \mathrm{C}\left(6.34 \mathrm{~W} / \mathrm{m}^{3}\right)$ and $21 \%$ higher at $43^{\circ} \mathrm{C}$, no steady power generation was observed at $55^{\circ} \mathrm{C}$. Low temperature to $10^{\circ} \mathrm{C}$ might have a huge effect on anode potential, especially at higher current, but increasing the temperature to $43^{\circ} \mathrm{C}$ had a main effect on the cathode performance when the MFCs have been established at $37^{\circ} \mathrm{C}$. The internal resistance of MFC was about $29 \Omega$ at $37^{\circ} \mathrm{C}$, and increased $62 \%$ and $303 \%$ when MFC switched to $30^{\circ} \mathrm{C}$ and $10^{\circ} \mathrm{C}$. Similarly, internal resistance increased $48 \%$ at $43{ }^{\circ} \mathrm{C}$. The effect of temperature on MFC performance was expressed by internal resistance, the higher the internal resistance of MFC, the lesser the power density obtained. The Columbic efficiencies were $8.65 \%$ at $30^{\circ} \mathrm{C}, 8.53 \%$ at $37{ }^{\circ} \mathrm{C}$, and $13.24 \%$ at $43{ }^{\circ} \mathrm{C}$. These results demonstrate that MFCs can effectively be operated over a wide range of temperatures.
\end{abstract}

Keywords: temperature; microbial fuel cell; power generation

\section{Introduction}

In the recent years, microbial fuel cell (MFC), a new bioelectrochemical device to generate electricity from biodegradable materials, has attracted wide-ranging interest.[1,2] Similar to the conventional fuel cells, MFCs are basically composed of an anode, on which microorganisms are used as the catalyst instead of abiotic catalysts such as platinum or palladium, and a cathode is an oxidant reduced by receiving electrons and protons moving from the anode. The electrons move along an external electrical wire for generating power while protons transfer through a proton exchange membrane (PEM) for charge neutralization.[3-5] However, the power density of MFC is still low compared with the conventional fuel cell, further amplifying the power density remains one of the greater challenges for realizing the practical applications of MFC.

As well known, the anode chamber of MFCs have to be operated in anaerobic atmosphere, and are intimately related to anaerobic digestion when its used for wastewater treatment.[6] Hence, the influence of parameters affecting anaerobic digesters should be assessed. Temperature is an important parameter in anaerobic digester and the characteristics of reactor operated in different temperatures have been widely studied and reported.[7-9] Generally, there are two optima for anaerobic digestion: a smooth one at about $32-42{ }^{\circ} \mathrm{C}$ for mesophilic microorganisms and a sharp one at $48-55^{\circ} \mathrm{C}$ for thermophilic microorganisms. Temperatures in the range of $40-45^{\circ} \mathrm{C}$ belong to the inactivated region for both mesophilic and thermophilic microorganisms. Methanogenics are sensitive to rapid changes of temperature. Thermophilic methanogens are more temperature-sensitive than mesophilics. Even small variations in temperature cause a substantial decrease in activity. Therefore, the temperature should be kept exactly within a range of $\pm 2{ }^{\circ} \mathrm{C}$. As conventional anaerobic digesters, MFCs are strongly affected by temperature. However, the possibility that electrogenesis, and some of the microorganisms involved, might be less sensitive to temperature variations than methanogenesis. To some extent, this is an exciting field of study whose results would have potential application in areas with large temperature variations. Some researches have been done to study the effect of temperature on MFC performance (Table 1), but there is no systematic information regarding the influence of temperature change on steady-operation MFCs. Hence, it was of interest for MFC research to analyse the influence of temperature change on their behaviour.

In this study, the performance of MFC was examined as a function of temperature over a range of $10-55^{\circ} \mathrm{C}$, the MFC system was first started up at temperature of $37^{\circ} \mathrm{C}$, then switched to operate at different temperatures $\left(10^{\circ} \mathrm{C}\right.$, $30^{\circ} \mathrm{C}, 43{ }^{\circ} \mathrm{C}$ and $55^{\circ} \mathrm{C}$ ).

\footnotetext{
*Corresponding author. Email: sunym@ms.giec.ac.cn
} 
Table 1. Experimental results of previous work at different temperatures.

\begin{tabular}{|c|c|c|c|c|c|c|c|c|c|}
\hline \multirow[b]{2}{*}{$\mathrm{T}^{\circ} \mathrm{C}$} & \multirow[b]{2}{*}{ System } & \multirow[b]{2}{*}{ Fuel } & \multirow[b]{2}{*}{ Inoculum } & \multicolumn{2}{|c|}{ Material } & \multirow[b]{2}{*}{$V_{\max }(\mathrm{mV})$} & \multirow[b]{2}{*}{$R_{\text {int }}(\Omega)$} & \multirow[b]{2}{*}{$P_{\max }\left(\mathrm{mV} / \mathrm{m}^{3}\right)$} & \multirow[b]{2}{*}{ Reference } \\
\hline & & & & Anode & Cathode & & & & \\
\hline 57 & Thermophilic MFCs & Glucose & TC60 & Graphite & & 387 & $9.25 \pm 0.15$ & $3.3-4.5^{\mathrm{a}}$ & [10] \\
\hline 50 & S-MFCs & Synthesis gas & sludge & Carbon felt & - & 655 & 45 & 34 & [11] \\
\hline 20 & S-MFCs & Acetate & Wastewater & Carbon paper & - & - & 200 & 660 & {$[12]$} \\
\hline 32 & & & & & & - & - & 720 & \\
\hline 10 & S-MFCs & Acetate & Sludge & Carbon cloth & - & $530-554$ & $72-112$ & $3.02-4.84$ & [13] \\
\hline 20 & & & & & & $561-563$ & $68-115$ & $3.18-4.29$ & \\
\hline 35 & & & & & & $630-611$ & $151-198$ & $2.14-3014$ & \\
\hline 56 & T-MFC & Acetate & Sludge & - & - & - & 470 & 37 & {$[14]$} \\
\hline 23 & New S-MFCs & - & Model leachate & Carbon cloth & & 300 & - & $606 \pm 57.5$ & {$[15]$} \\
\hline 35 & & & & & & 290 & & $479.6 \pm 23.1$ & \\
\hline 23 & S-MFCs & & & & & 220 & & $90.5 \pm 23.1$ & \\
\hline 35 & & & & & & 100 & & $55.6 \pm 4.7$ & \\
\hline 15 & T-MFC & Acetate & Wastewater & Carbon paper & & 25 & No successful operation & & [16] \\
\hline 22 & & & & & & $497 \pm 6$ & 1000 & $46^{\mathrm{a}}$ & \\
\hline 30 & & & & & & $537 \pm 8$ & 430 & $70^{\mathrm{a}}$ & \\
\hline 4 & S-MFCs & Acetate & $\begin{array}{l}\text { Solution from an } \\
\text { MFC }\end{array}$ & $\begin{array}{l}\text { Graphite fibre } \\
\text { brush }\end{array}$ & Carbon cloth & No successful operation & & & {$[17]$} \\
\hline 10 & & & & & & & & & \\
\hline 15 & & & & & & $512 \pm 2$ & - & $709 \pm 10^{\mathrm{a}}$ & \\
\hline 20 & & & & & & $545 \pm 3$ & & $940 \pm 6^{\mathrm{a}}$ & \\
\hline 30 & & & & & & $563 \pm 6$ & & $1260 \pm 10^{\mathrm{a}}$ & \\
\hline 15 & S-MFCs & Sodium acetate & Sludge & $\begin{array}{l}\text { Carbon fibre } \\
\text { brush }\end{array}$ & Carbon cloth & 500 & 362 & $260^{\mathrm{a}}$ & [18] \\
\hline 25 & & & & & & 540 & 212 & $591^{\mathrm{a}}$ & \\
\hline
\end{tabular}

Notes: S-MFCs, single-chamber MFC; T-MFCs, two-chamber MFC; -, no reported.

a the units is $\mathrm{mV} / \mathrm{m}^{2}$ 


\section{Materials and methods}

\subsection{MFC construction}

MFCs were two-chamber, rectangle-shaped reactors having equal volume and dimension $(500 \mathrm{~mL} ; 5.0 \times 1.0 \times 1.0 \mathrm{~cm})$ as previously described.[19] Each compartment contained one piece of graphite plate $\left(66 \mathrm{~cm}^{2}\right)$ as electrodes. The anode and cathode chambers were separated by a PEM (Nafion 117 , Dupond, $10 \times 10 \mathrm{~cm}$ ). The membrane was pretreated by boiling in $\mathrm{H}_{2} \mathrm{O}_{2}(3 \%)$ and deionized water followed by $3-5 \% \mathrm{H}_{2} \mathrm{SO}_{4}$ and deionized water, each for $2 \mathrm{~h}$, and then stored in water prior to use. Titanium wires $(0.5 \mathrm{~mm}$ diameter) were utilized as leads for both compartment electrodes. The wires were connected to an external resistance of $510 \Omega$ during the MFC operation.

The sludge from river mud was used as an inoculum in the anode compartment of the MFC. Acetate $(4 \mathrm{~g} / \mathrm{L})$ was used as an energy source in a medium amended with inorganic salt solution $\left(12.8 \mathrm{~g} / \mathrm{L} \mathrm{Na} \mathrm{NPOO}_{4}, 3 \mathrm{~g} / \mathrm{L}\right.$ $\left.\mathrm{KH}_{2} \mathrm{PO}_{4}, 1.0 \mathrm{~g} / \mathrm{L} \mathrm{NH} \mathrm{Nl}_{4} \mathrm{Cl}, 0.5 \mathrm{~g} / \mathrm{L} \mathrm{NaCl}\right)$. Potassium ferricyanide $(50 \mathrm{mmol} / \mathrm{L})$ was added into acthodeic compartment as the electron acceptor, and the same inorganic salt solution was used as the buffer solution $(\mathrm{pH}=7.09)$.

\subsection{MFC operation}

All MFCs systems were operated in the fed-batch mode, $20 \%(\mathrm{~V} / \mathrm{V})$ of sludge was inoculated and $80 \%(\mathrm{~V} / \mathrm{V})$ influent solution was added. The MFCs were first operated at $37^{\circ} \mathrm{C}$ for $96 \mathrm{~d}$ before being tested at lower temperature. When the stable operation was obtained, the operation temperatures were then switched to $10^{\circ} \mathrm{C}, 30^{\circ} \mathrm{C}, 43^{\circ} \mathrm{C}$ and $55^{\circ} \mathrm{C}$. The temperature was increased from $43-55^{\circ} \mathrm{C}$ with stepwise increments of $2{ }^{\circ} \mathrm{C}$ per day as done in the process of anaerobic digestion. Reactors were refilled each time when the voltage decreased to less than $100 \mathrm{mV}$, forming a complete cycle of operation.

\subsection{Analytics and calculations}

Cell voltages were measured across the external circuit containing a resistor using a multimeter. Current $(I)$ was calculated as $I=U / R$, where $R(\Omega)$ is the external circuit resistance. Power $(P)$ was calculated as $P=U^{2} / R$. The volumetric power density $\left(\mathrm{W} / \mathrm{m}^{3}\right)$ was calculated based on the volume of chamber $(500 \mathrm{~mL})$. Polarization curves were obtained by changing the external resistor after leaving the reactor under open circuit potential for two hours, with each measurement taken under maximum power output conditions. The internal resistance, $r$, was calculated from the slope of the voltage-current graph according to $U=E-I r$, where $E$ was the electromotive force of the cell. Columbic efficiency (CE, the number of electron recovered as current in the reactor to the total electron stored in biomass) was calculated based on COD removal as previously described.[20] $\mathrm{Ag} / \mathrm{AgCl}$ reference electrodes were placed into the anode and cathode compartments to determine individual electrode potentials. COD was determined by HACA-DR2700.

\section{Results}

\subsection{Voltage of MFC under different temperatures}

When MFCs were initially operated at $37^{\circ} \mathrm{C}$, and then switched to $10^{\circ} \mathrm{C}, 30^{\circ} \mathrm{C}$ and $43^{\circ} \mathrm{C}$, stable power generation was obtained at these temperatures (Figures 1 and 2). The maximum voltage of $660 \pm 4 \mathrm{mV}$ was obtained at $10^{\circ} \mathrm{C}, 687 \pm 22 \mathrm{mV}$ at $30^{\circ} \mathrm{C}, 672 \pm 11 \mathrm{mV}$ at $37^{\circ} \mathrm{C}$, and $665 \pm 6 \mathrm{mV}$ was produced at $43^{\circ} \mathrm{C}$. When the temperature of MFCs was increased to $55^{\circ} \mathrm{C}$, no appreciable voltage was obtained. Similar results were reported in previous studies. It was found that the MFCs started up at the temperatures of $4{ }^{\circ} \mathrm{C}$ and $10^{\circ} \mathrm{C}$ did not produce appreciable power even after very long operation times, but if reactors were first operated at a higher temperature of $30^{\circ} \mathrm{C}$, and

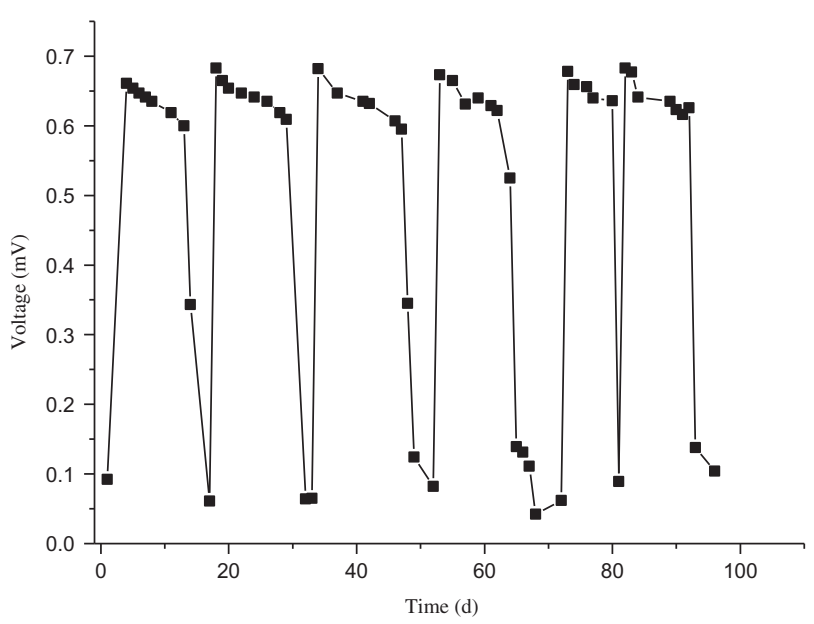

Figure 1. Volrage of MFCs at $37^{\circ} \mathrm{C}$.

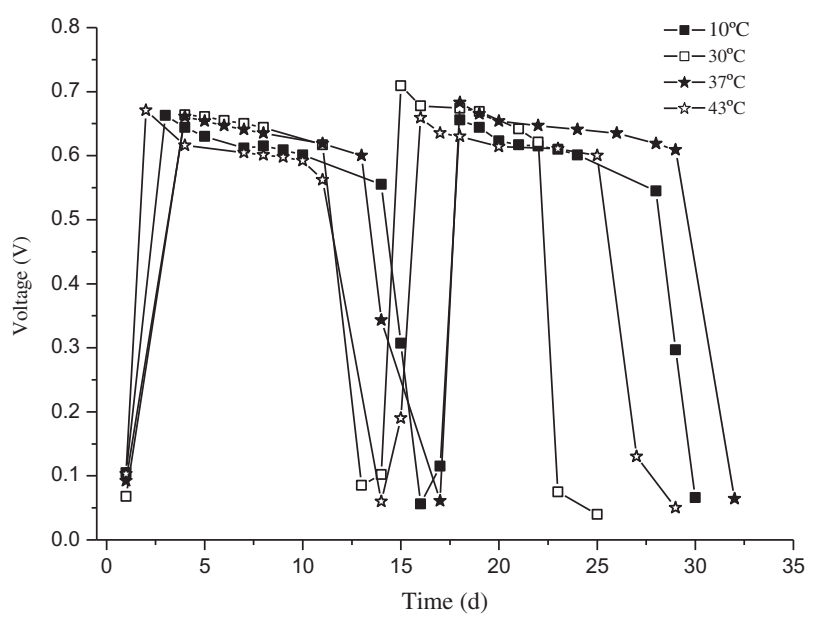

Figure 2. Variation of voltage with time under different temperature change. 

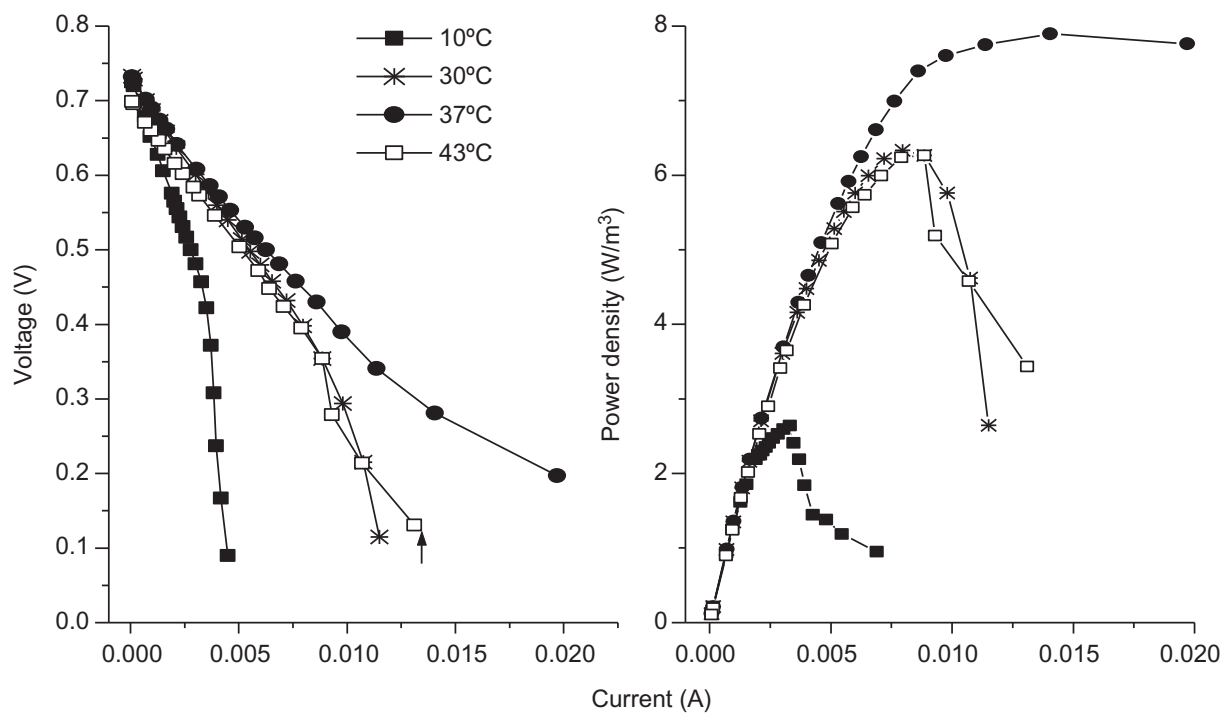

Figure 3. Voltage and Power density as a function of current under different temperature conditions.

then switched to these lower temperatures, the maximum voltages of $425 \pm 2 \mathrm{mV}\left(4^{\circ} \mathrm{C}\right)$ and $484 \pm 3 \mathrm{mV}\left(10^{\circ} \mathrm{C}\right)$ were obtained, respectively.[17] But the amount of maximum voltage is larger here than Cheng's observation. This difference could be due to the different construction of MFCs and electron acceptor. Previous studies found that using ferricyanide shows much greater power generation than those with oxygen due to the fact that there is little polarization of the cathode; therefore, the achieved cathode potential is quite close to that calculated for standard conditions, while oxygen is predicted to have a higher cathode potential than ferricyanide, in practice the potentials achieved using oxygen are much lower than theoretical values.[21,22] In two-chamber MFCs tests, Oh et al. [23] found that replacing the aqueous cathode using oxygen with ferricyanide increased the power output.

\subsection{Overall performance of MFC under different temperatures}

To evaluate the influence of temperature on performance of MFCs, the voltage and power densities as a function of current were examined by varying external resistance from 9000 to $10 \Omega$ (Figure 3). The maximum power density of MFCs at $10^{\circ} \mathrm{C}, 30^{\circ} \mathrm{C}, 37^{\circ} \mathrm{C}$, and $43^{\circ} \mathrm{C}$ were $2.64,6.34$, 7.89 and $6.26 \mathrm{~W} / \mathrm{m}^{3}$. Compared with $37^{\circ} \mathrm{C}$, power density of $30^{\circ} \mathrm{C}$ reduced $24 \%$, and continued decreasing by $199 \%$ at $10^{\circ} \mathrm{C}$. Likewise, power density of $43^{\circ} \mathrm{C}$ reduced $21 \%$. It was demonstrated that power density of MFCs was seriously affected by operation temperatures. The MFCs first established at $37^{\circ} \mathrm{C}$ and then switched to $10^{\circ} \mathrm{C}$, a stable power generation was obtained, which was consistent with other studies. This showed that the bacteria were capable of functioning at different temperatures when the biofilm formed, and some of the bacteria involved might have higher tolerance to lower temperature.[6] Lower power density was obtained when the temperature was increased to $43^{\circ} \mathrm{C}$, this result was in disagreement with the findings of Behera et al.,[24] who found that maximum power density of $34.38 \mathrm{~mW} / \mathrm{m}^{2}$ was achieved at an operating temperature of $40^{\circ} \mathrm{C}$. There was no stable power generation observed when the MFC switched to $55^{\circ} \mathrm{C}$, this could be due to the composition of bacterial communities being different in mesophilic and thermophilic conditions. The dominant bacteria in the anode compartment of thermophilic MFCs was phylogenetically close to an uncultured clone.[25] Shewanella putrefaciens, Geobacter sulfurreducens and Rhodoferax ferrireducens were usually presented in MFCs operated in mesophilic condition. [25,26]

During the generation of the polarization curves, the values of the anode and cathode potential versus a standard $\mathrm{Ag} / \mathrm{AgCl}$ reference electrode were also recorded (Figure 4). Decreasing the temperature from $43^{\circ} \mathrm{C}$ to $-30^{\circ} \mathrm{C}$, the

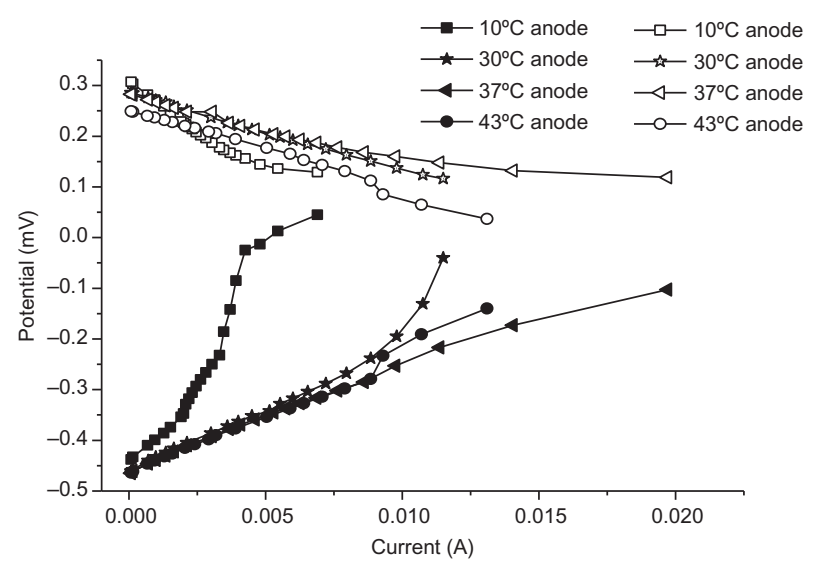

Figure 4. Anode and cathode potentials as function of current density at different temperature. 
anode potential showed almost the same value over a current range of $0.076-7.2 \mathrm{~mA}$, but at higher current $(>7.2 \mathrm{~mA})$ the higher anode potential was obtained at $30^{\circ} \mathrm{C}$. The cathode working potential of MFC operated at $30^{\circ} \mathrm{C}$ was also comparable to that operated at $37^{\circ} \mathrm{C}$ for current in the range of $0.076-11.5 \mathrm{~mA}$. but the higher cathode potential was obtained at $37^{\circ} \mathrm{C}$ at higher current $(>11.5 \mathrm{~mA})$. Further decreasing the temperature to $10^{\circ} \mathrm{C}$, both anode and cathode were affected, and led to a decrease in maximum power density. For example, at a current of $0.003 \mathrm{~A}$, reducing the operating temperature from $37^{\circ}$ to $-10^{\circ} \mathrm{C}$ reduced anode performance as shown by an increase in the anode potential by $36.22 \%$ (from -392 to $-250 \mathrm{mV}$ ) and the cathode potential decreased by $16.66 \%$ (from 246 to $187 \mathrm{mV}$ ). And the higher anode potential was obtained at higher current, for example, at a current of $0.00392 \mathrm{~A}$, anode potential increased by $76.96 \%$ (from -369 to $-85 \mathrm{mV}$ ) and the cathode potential decreased by $26.36 \%$ (from 220 to $162 \mathrm{mV}$ ) when the operating temperature switched from $37^{\circ} \mathrm{C}$ to $-10^{\circ} \mathrm{C}$. It can be seen that lower temperature might have a huge effect on anode potential, especially at higher current. The anode open circuit voltages $\left(\mathrm{OCV}_{\mathrm{an}}\right)$ of MFC at the temperature of $30^{\circ} \mathrm{C}, 37^{\circ} \mathrm{C}$ and $43{ }^{\circ} \mathrm{C}$ were similar to, but the $\mathrm{OCV}_{\text {an }}$ at $10^{\circ} \mathrm{C}$ was only $447 \mathrm{mV}$. This suggested that the activity of microbial was partly inhibited, this is consistent with other studies,[27] it was the strategy of anodic community to acclimatize itself to environmental change and to gain more energy for vital activity under lower temperature. Lower cathode potential was found when the operated temperature switched to $43^{\circ} \mathrm{C}$. For example, at a current of $0.003 \mathrm{~A}$, anode potential reduced by $0.51 \%$ (from -392 to $-398 \mathrm{mV}$ ) and the cathode potential decreased by $15.73 \%$ (from 248 to $209 \mathrm{mV}$ ). Thus, increasing temperature to $43^{\circ} \mathrm{C}$ had a main effect on the cathode performance.

The internal resistances of MFC were about $117 \Omega$ at $10^{\circ} \mathrm{C}, 47 \Omega$ at $30^{\circ} \mathrm{C}, 29 \Omega$ at $37^{\circ} \mathrm{C}$ and $43 \Omega$ at $43^{\circ} \mathrm{C}$, respectively (Figure 5). Internal resistances determined by

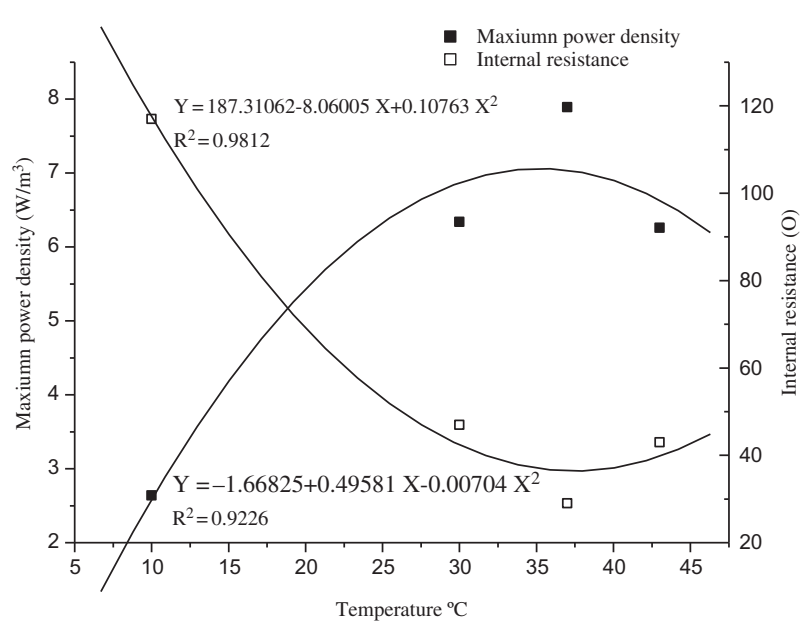

Figure 5. Maximum power density and internal resistance as a function of operating temperature. linear regression were associated with high values of coefficient of determination in the range $0.989-0.996$, i.e. the regressions were significant. Compared with $37^{\circ} \mathrm{C}$, internal resistance of $30^{\circ} \mathrm{C}$ increased to $62 \%$, and continued to increase by $303 \%$ at $10^{\circ} \mathrm{C}$. Similar result was found at $43{ }^{\circ} \mathrm{C}$ with the internal resistance increased to $48 \%$. This implied that the effect of temperature on MFC performance was expressed by the internal resistance of the cell, the higher the internal resistance of MFC, the less the power density obtained. As shown in Figure 4, the relevance between operating temperature and the maximum power density could be well fitted by: $Y=-1.66825+$ $0.49581 X-0.00704 X^{2}\left(R^{2}=0.922\right)$. Cheng et al. found that power production increased linearly in the range of $4-30^{\circ} \mathrm{C}$. This difference could be due to the operating was temperature, $10^{\circ} \mathrm{C}, 30^{\circ} \mathrm{C}, 37^{\circ} \mathrm{C}, 43$, and $55^{\circ} \mathrm{C}$ used in these experiments, while it was $4-30^{\circ} \mathrm{C}$ for Cheng et al.

The CEs and COD removal rate at the different temperature was calculated and listed in Figure 6. In all experiments, the COD removals were $94-99 \%$. The CEs were $8.65 \%$ at $30{ }^{\circ} \mathrm{C}, 8.53 \%$ at $37^{\circ} \mathrm{C}$, and $13.24 \%$ at $43^{\circ} \mathrm{C}$. Similar results were reported by previous studies. Liu et al. [12] found that $\mathrm{CE}$ decreased from $25 \%$ to $17 \%$ when the temperature was decreased from $32^{\circ} \mathrm{C}$ to $20^{\circ} \mathrm{C}$, and Cheng et al. [17] reported a decrease from $17 \%$ to $15 \%$. Higher COD removal rate was accompanied by lower coulombic efficiencies, similar results were reported by other researchers. These results could be explained by several effects. First, the open-style chamber was used for cathode, and oxygen diffusion through the PEM was mostly caused by part of PEM directly contacted with air. Feng et al. [28] thought that the low CEs result in part due to substrate depletion by aerobic bacteria sustained by oxygen transfer through the cathode. Second, due to the consumption of the easily degradable carbon source by co-existent methanogenic and anodophilic microorganisms.[29]

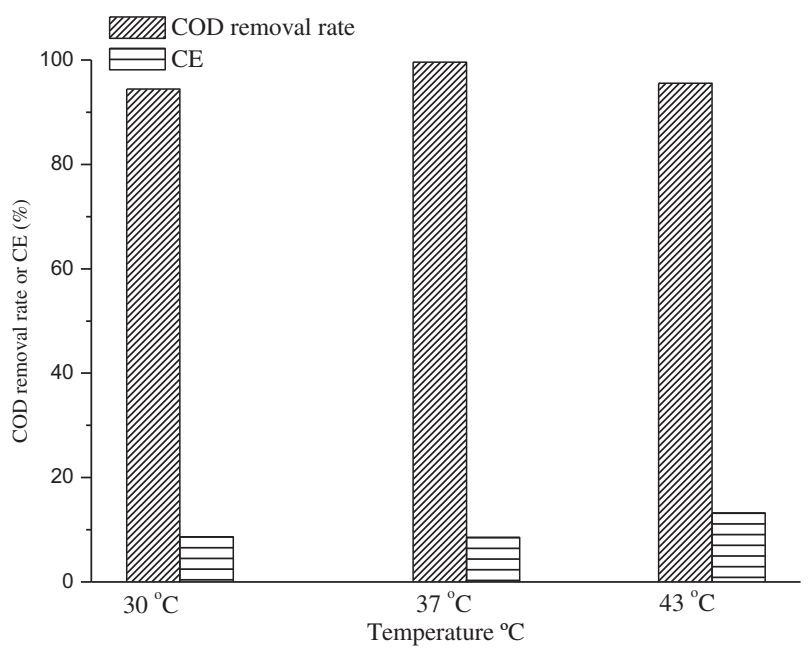

Figure 6. variety of COD removal rate and coulombic efficiency with different temperature. 


\section{Conclusion}

It was shown that power generation of MFC was greatly influenced by the operating temperature. Electricity can be generated by $\mathrm{MFC}$ in temperature ranges from $10^{\circ} \mathrm{C}$ to $43^{\circ} \mathrm{C}$, but no steady power generation was observed at $55^{\circ} \mathrm{C}$. When the temperature increased from $10^{\circ} \mathrm{C}$ to $33{ }^{\circ} \mathrm{C}$, the power density increased from 2.64 to $6.34 \mathrm{~W} / \mathrm{m}^{3}$ accordingly. Further raising temperature to $43{ }^{\circ} \mathrm{C}$, the power density decreased to $6.26 \mathrm{~W} / \mathrm{m}^{3}$. The effect of temperature on MFC performance was expressed by the internal resistance of the cell, the higher the internal resistance of MFC, the lesser the power density obtained.

\section{Funding}

The research was supported by National Natural Science Foundation of China [grant number 21006105].

\section{References}

[1] Verstraete W, Rabaey K. Microbial fuel cells: novel biotechnology for energy generation. Trends Biotechnol. 2005;23:291-298.

[2] Logan BE. Simultaneous wastewater treatment and biological electricity generation. Water Sci Technol. 2005;52: 31-37.

[3] Wrighton KC, Agbo P, Warnecke F. A novel elological role of the firmicutes identified in thermophilic microbial fuel cells. The ISME J. 2008;2:1146-1156.

[4] Zinner D, Ramaswami A, Ren Z. Scale-up microbial fuel cell for direct conversion of food waste to electricity. RMSAWWA. 8th Annual Student Research conference; 2011 May 17; University of New Mexico, NM.

[5] Rahimnejad M, Ghoreyshi AA, Najafpour GD. A novel microbial fuel cell stack for continuous production of clean energy. Int J Hydrogen Energy. 2012;37:5992-6000.

[6] Larrosa-Guerrero A, Scott K, Head IM. Effect of temperature on the performance of microbial fuel cells. Fuel. 2010;89:3985-3994.

[7] VanLier JB, Martin JLS, Lettinga G. Effect of temperature on the anaerobic thermophilic conversion of volatile fatty acids by dispersed and granular sludge. Water Res. 1966;30: 199-207.

[8] Masse DI, Masse L, Croteau F. The effect of temperature fluctuations on psychrophilic anaerobic sequencing batch reactors treating swine manure. Bioresour Technol. 2003;89:57-62.

[9] Li LH, Li D, Sun YM. Effect of temperature and solid concentration on anaerobic digestion of rice straw in South China. Int J Hydrogen Energy. 2010;13:7261-7266.

[10] Carver SM, Vuoriranta P, Tuovinen OH. A thermophilic microbial fuel cell design. J Power Sources. 2011;8: 3757-3760.

[11] Hussain A, Mehta P, Raghavan V. The performance of a thermophilic microbial fuel cell fed with synthesis gas. Enzyme Microb Technol. 2012;3:163-170.
[12] Liu H, Cheng SA, Logan BE. Power generation in fed-batch microbial fuel cells as a function of ionic strength, temperature, and reactor configuration. Environ Sci Technol. 2005; 14:5488-5493.

[13] Michie IS, Kim JR, Dinsdale RM. Operational temperature regulates anodic biofilm growth and the development of electrogenic activity. Appl Microbiol Biotechnol. 2011;2:419-430.

[14] Wrighton KC, Agbo P, Warnecke F. A novel ecological role of the Firmicutes identified in thermophilic microbial fuel cells. Isme J. 2008;11:1146-1156.

[15] Vazquez-Larios AL, Solorza-Feria O, Vazquez-Huerta G. Internal resistance and performance of microbial fuel cells: influence of cell configuration and temperature. J New Mat Electr Sys. 2011;2:99-105.

[16] Min B, Roman OB, Angelidaki I. Importance of temperature and anodic medium composition on microbial fuel cell (MFC) performance. Biotechnol Lett. 2008;7: 1213-1218.

[17] Cheng SA, Xing DF, Logan BE. Electricity generation of single-chamber microbial fuel cells at low temperatures. Biosens Bioelectron. 2011;5:1913-1917.

[18] Liu LH, Tsyganova O, Lee DJ. Anodic biofilm in singlechamber microbial fuel cells cultivated under different temperatures. Int J Hydrogen Energy. 2012;20:15792-15800.

[19] Kong XY, Sun YM, Yuan ZH. Effect of cathode electronreceiver on the performance of microbial fuel cells. Int J Hydrogen Energy. 2010;13:7224-7227.

[20] Logan BE, Hamelers B, Rozendal RA. Microbial fuel cells: methodology and technology. Environ Sci Technol. 2006;17:5181-5192.

[21] ter Heijne A, Hamelers HHV, de Wilde V, Rozendal RR, Buisman CJN. Ferriciron reduction as an alternative for platinum-based cathodes in microbial fuel cell. Environ Sci Technol. 2006;40:5200-5205.

[22] You SJ, Zhao QL, Zhang JN. A microbial fuel cell using permanganate as the cathodic electron acceptor. J Power Sources. 2006;2:1409-1415.

[23] Oh S, Min B, Logan BE. Cathode performance as a factor in electricity generation in microbial fuel cells. Environ Sci Technol. 2004;18:4900-4904.

[24] Behera M, Murthy SSR, Ghangrekar MM. Effect of operating temperature on performance of microbial fuel cell. Water Sci Technol. 2011;4:917-922.

[25] Jong BC, Kim BH, Chang IS. Enrichment, performance, and microbial diversity of a thermophilic mediatorless microbial fuel cell. Environ Sci Technol. 2006;20:6449-6454.

[26] Logan BE. Exoelectrogenic bacteria that power microbial fuel cells. Nat Rev Microbiol. 2009;5:375-381.

[27] Wang X, Feng YJ, Lee H. Electricity production from beer brewery wastewater using single chamber microbial fuel cell. Water Sci Technol. 2008;7:1117-1121.

[28] Feng Y, Wang X, Logan BE. Brewery wastewater treatment using air-cathode microbial fuel cells. Appl Microbiol Biotechnol. 2008;5:873-880.

[29] Zhang LB, Li C, Ding LL. Influences of initial $\mathrm{pH}$ on performance and anodic microbes of fed-batch microbial fuel cells. J Chem Technol Biotechnol. 2011;9:12261232 . 